Journal of English Teaching and Learning Issues, 3 (2) page 115 - 130, 2020 ISSN: 2615-3920 EISSN: 2685-4473

DOI: $10.21043 /$ jetli.v3i2.8545

\title{
A Comparative Study Between Human Translation and Machine Translation as an Interdisciplinary Research
}

\section{Zainuddin Hasibuan}

Department of English Education Study Program, Faculty of Tarbiyah and Teacher Training Study, IAIN Lhokseumawe, Aceh, Indonesia

\section{zainuddinhasib@gmail.com}

\begin{abstract}
Research purpose of the research is to determine the difference between human translation and machine translation. The data sources for this article come from several references, books, journals and articles related to the title of the discussion. Research findings of the research are that human translation is more effective and easier to understand when compared to machine translation which can only translate literal sentences or words without understanding the intent and purpose of the intended target language. So, machine translation language mainly focuses on the source language without paying attention to the target language. In terms of semantic meanings in machine translation, it is far away from the truth of the meaning it has when compared to the meaning of human translations. Therefore, machine translation can be said to be a literal translation that applies in general. So, the role of human translation is still bigger in the correct translation.
\end{abstract}

KEYWORDS:

Comparative;

Human;

Machine;

Study;

Translation

\section{Introduction}

In translation subject, many students even many people are still confuse about the difference between human and machine translation, what is their advantage and their weaknesses. This is a very seriously problem that should be discussed to know the correct answer. It is also necessarily to inform in order to get good choice to determine a good result especially in doing assignment and business. A variety of definitions exist for machine aided translation. Between them, these definitions place machine aided translation on a scale reaching from human translation in the proper sense of the word to fully automatic machine translation (Baker, 2015). 
Talking about human and machine translation, the mechanization of translation has been one of humanity's oldest dreams. In the twentieth century it has become a reality, in the form of computer programs capable of translating a wide variety of texts from one natural language into another. But, as ever, reality is not perfect. There are no 'translating machines' which, at the touch of a few buttons, can take any text in any language and produce a perfect translation in any other language without human intervention or assistance. That is an ideal for the distant future, if it is even achievable in principle, which many doubt.

Machine translation was a matter of serious speculation long before there were computers to apply to it; it was one of the first major problems to which digital computers were turned; and it has been a subject of lively, sometimes acrimonious, debate ever since. Machine translation has claimed attention from some of the keenest minds in linguistics, philosophy, computer science, and mathematics. At the same time it has always attracted the lunatic fringe, and continues to do so today.

Human and machine translation have an important role in the translation subject. They always help the translator to create a good result in translating source text into target text. Therefore, a good translator is surely able to know when machine translation can be used and when also human translation can be used properly. Thus, this research will try to find out the differences between human and machine translation.

A translation is a piece of writing or speech that has been translated from a different language (Collin, 2006). It means that in a translation there is a process of transfering language from the source of langugae (SL) into the target of language (TL). The text in the source of language (SL) and the target of the language $(T L)$, both of them should be understood by the translator especially about its lexical elements of language and grammatical structure of the language.

According to Newmark, translation theory is concerned mainly with determining appropriate translation methods for the widest possible range of texts or text-categories. It also provides a frame work of principles, restricted rules and hints for translating texts and criticizing translations, a background for problem solving (Newmark, 2000). A rigorous theory of translation would also include 
something like a practical evaluation procedure with specific criteria (Graham, 1981). A good survey of the theories of translation is perhaps best furnished by $E$. Nida: who avers that due to the fact that translation is an activity involving language there is a sense in which any and all theories of translation are linguistic (Nida, 1969).

Translation is activity of changing the language and tried to find an equivalent idea among the language. When doing translation, the translator not only transferred the message but also pay attention on the style both expression and language.

\section{Method of Research}

This research used descriptive qualitative approach where descriptive qualitative is a research used to describe a natural phenomenon or man's engineering. This research investigates forms, activities, characteristics, changes, relationship, similarities and differences with another phenomenon (Sukmadinata, 2009).

The data of this research is in the form of word, phrase, clause and sentence which contains the translation texts from human and machine translation by using data collection technique in the form of words, phrases, clauses and sentences based on the scope of research. After collecting the data, the data was analyzed descriptively by using technique of three steps. They are data condensation, data display and conclusion drawing/verification.

\section{Findings}

Machine translation is not that perfect rendering of the source text into the target text. The point is that the translated text, still, bears much of the traits characterizing the language of the source text; therefore, much should be said about how the use of language is violated as well as the meaning. Simultaneously, some focus is to be on to what extent the human translation has succeeded in transforming the source text into the target text depicting whether the translated text has the same effect as the source text.

The machine translation is a literal translation or instead a word-for-word translation; the reader can easily notice that there is no flexibility in the machine 
translation in that each word in the source text has been substituted orderly by another in the machine translation.

The human translator is capable of avoiding what have been criticized in the machine translation. The human version is a structure respecting and its focus has been in both the source text, in an act of comprehension, and the target text, in an act of producing a perfect translation. The human translator's flexibility allows them to move from language into another bearing in their minds the difference of structures between languages

\section{Discussion}

\section{Machine Translation}

The idea of machine translation may be traced back to the 17th century. In 1629, René Descartes proposed a universal language, with equivalent ideas in different tongues sharing one symbol. The field of "machine translation" appeared in Warren Weaver's Memorandum on Translation (1949). The first researcher in the field, Yehosha Bar-Hillel, began his research at MIT (1951). A Georgetown University MT research team followed (1951) with a public demonstration of its Georgetown-IBM experiment system in 1954. MT research programs popped up in Japan and Russia (1955), and the first MT conference was held in London (1956). Researchers continued to join the field as the Association for Machine Translation and Computational Linguistics was formed in the U.S. (1962) and the National Academy of Sciences formed the Automatic Language Processing Advisory Committee (ALPAC) to study MT (1964).

Real progress was much slower, however, and after the ALPAC report (1966), which found that the ten-year-long research had failed to fulfill expectations, funding was greatly reduced. According to a 1972 report by the Director of Defense Research and Engineering (DDR\&E), the feasibility of large-scale MT was 
reestablished by the success of the Logos MT system in translating military manuals into Vietnamese during that conflict.

\section{The Emergence of Machine Translation and its evolution.}

The competition towards establishing more business with different parts of the world incited advanced countries in technology to look for easy and quick ways for communication. Hence, there emerged a type of translation known as Machine Translation for the process of translation was carried out by machines. The specific date when this type of translation did emerge as stated in Olivia Craciunescu's article " Machine Transltion and Computer-Assisted Translation: a New Way of Translating" is believed to be "the beginnings of the Cold War... in the 1950s competition between the United States and the Soviet Union".

Machine Translation as a new emerging discipline in the field of translation study has come to fill the void existing due to the small number of good and acknowledged translators. It was an advantageous way of translation in that it saves both time and money; a large quantity of articles and documents were easily translated in a short time with a low amount of money.

Therefore, the fact that machine translation is carried out by machines does not mean that humans are totally absent from the process of translation; nevertheless, there is human intervention, as in the case of Computer-Assisted Translation and in other cases of some translating machine programs that are limited in terms of the vocabulary provided by their programmed dictionaries. In this regard, the role of human translators is manifested in what is known as the process of pre-editing of the intended source text to be translated, and post-editing of the translated version provided by the machine translation.

Approaches 


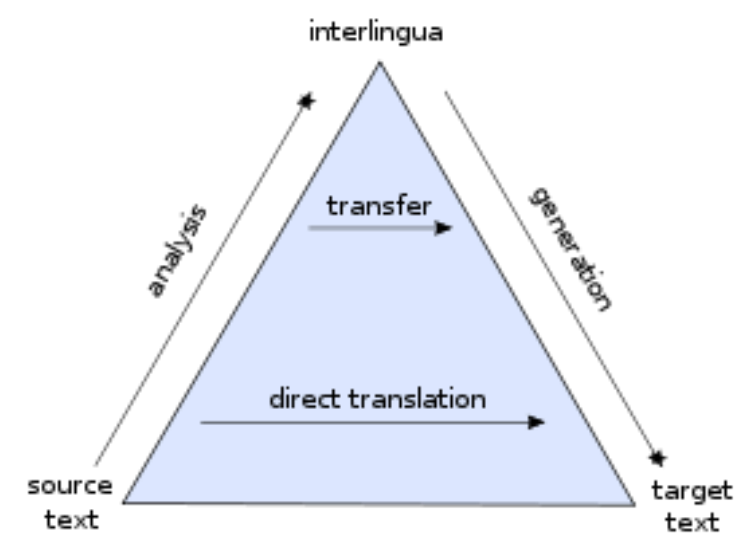

Bernard Vauquois' pyramid showing comparative depths of intermediary representation, interlingual machine translation at the peak, followed by transferbased, then direct translation. Machine translation can use a method based on linguistic rules, which means that words will be translated in a linguistic way - the most suitable (orally speaking) words of the target language will replace the ones in the source language.It is often argued that the success of machine translation requires the problem of natural language understanding to be solved first. Generally, rule-based methods parse a text, usually creating an intermediary, symbolic representation, from which the text in the target language is generated. According to the nature of the intermediary representation, an approach is described as interlingual machine translation or transfer-based machine translation. These methods require extensive lexicons with morphological, syntactic, and semantic information, and large sets of rules.

Given enough data, machine translation programs often work well enough for a native speaker of one language to get the approximate meaning of what is written by the other native speaker. The difficulty is getting enough data of the right kind to support the particular method. For example, the large multilingual corpus of data needed for statistical methods to work is not necessary for the grammarbased methods. But then, the grammar methods need a skilled linguist to carefully design the grammar that they use.To translate between closely related languages, the technique referred to as rule-based machine translation may be used. 


\section{Human Translation}

Any attempt to replace Human Translation totally by machine translation would certainly face failure for, due to a simple reason, there is no machine translation that is capable of interpretation. For instance, it is only the human translator who is able of interpreting certain cultural components that may exist in the source text and that can not be translated in terms of equivalent terms, just like what automatic translation does, into the language of the target text. In addition, it is widely agreed upon that one of the most difficult tasks in the act of translation is how to keep the same effect left by the source text in the target text. The automatic translation, in this regard, has proved its weakness, most of the time, when compared with a human translation. The human translator is the only subject in a position to understand the different cultural, linguistic and semantic factors contributing to leaving the same effect, that is left in the source text, in the target text.

It is an undeniable fact that automatic translation is regarded as a tool for producing quick and great number of translated texts; nevertheless, the quality of the translation is still much debatable. The automatic translation, for instance, cannot usually provide a definite translation for words that bear different vowel forms such as the Arabic term /kotob/ which means in English "books". The term in many translation programs, when translating from Arabic into English, is confused with the other Arabic term /kataba/ which means in English the verb "to write".

On the other hand, no human translator would make the same mistake for their ability to read words with different diacritic marks or vowels. In some cases, the automatic translation cannot even provide equivalent terms in the target language leaving them as they are in the source text. Actually, this part in the paper has been dedicated mainly to demonstrate some of the general differences between automatic translation and human translation which make the latter much favorable than the former. The human translation process may be described as decoding the meaning of the source text and re-encoding this meaning in the target language.

\section{Comparism Between Human and Machine Translation}


General-use machine-translation engines, like Google Translate, tend to give very literal dictionary translations, and in the case of translating non-Latin alphabets like Arabic, Cyrillic or Chinese into English, can often return complete nonsense. But some sophisticated translation companies have begun to offer machinetranslation engines that are trained by human translators.

In these instances, the translation engine is "fed" with as much of a business's professionally translated content as possible for all of its different language markets, so that the machine begins to recognise the terminology that's particular to its sector, and for each of its different markets. To give a very broad example, if a business is fashion, a machine translation tool designed for English to French would recognise that a specific type of blazer or jacket should be translated as a "smoking jacket", not with the dictionary translation of "veste".

For high-volume, low-quality translations, it might be sufficient to simply use the machine-translated content (if a few inaccuracies aren't likely to cause major troubles). If a business needs a higher quality translation, though, the most cost effective option is post-edited machine translation. This is where the content is fed through the machine-translation engine and then checked afterwards by a human translator to ensure there are no errors, and that the content is correctly localised for its intended region (no jarring cultural references, language and spelling choices).

The professional translator will then feed any adjustments they make back into the translation engine, so it gets more efficient and knowledgeable the more it gets used.

\section{Making multilingual easy}

Managing translation and multilingual content by hand can be extremely timeconsuming: emailing back and forth, checking content, debating over changes etc. And with an ecommerce website, there's a lot of content to get through, from carefully tailored landing pages through to constantly changing product catalogue, client communications, front page updates, and so forth.

But businesses can eliminate that administration time by using an API (a corporation) to connect their website with professional human translators and intelligent machine-translation engines, so they can quickly and efficiently 
translate their website content from popular ecommerce platforms like Magento into different languages. The API connects a site's platform directly with the translation system, and allows businesses to set up the rules as to what content gets sent automatically for translation, and what gets sent individually.

In general, the art of translation and translation services don't just depend on word-for-word replacement of a source language text with a target language equivalent. If that were the case, then human translation would be rendered obsolete by machine translation. At the moment though, all professional translation is best done with human translation and the occasional machine translation service.

\section{The Shortcomings of Machine Translation}

To illustrate, a computer translation assistant once automatically translated an article about the former First Lady of the United States, Laura Bush, in French. Although computer translators are programmed to discern certain expressions and figures of speech, each and every instance of "Laura Bush" found in the article ended up being translated as "le buisson de Laura". More to the point, "Bush" was transliterated by the machine as a noun instead of a family name, and "buisson" is incidentally French slang for "vagina" to boot.

As long as automatic machine translators lack self-awareness or insight equal to that of a normal human being, human translation will always be needed. At any rate, let's now take a good look at what a high-grade, topnotch professional translation really looks like. To reiterate, it's important to view a translator as an expert craftsman; a linguist, a specialist, and a wordsmith all-in-one multiplied by two or more different languages.

\section{What about Human Translation?}

So does this spell imminent doom for human multi-linguists? Not quite yet. As mentioned above, for quality translations where errors are likely to cause problems, such as product descriptions, at the very least businesses will want a human translator to post-edit the machine translations, to ensure accuracy.

The US Department of Labor put it best in a 2014 report, writing, "It is seldom, if ever, sufficient to use machine translation without having a human who is trained 
in translation available to review and correct the translation to ensure that it is conveying the intended message."And more importantly, for carefully tailored marketing content, such as a landing page, businesses will definitely need a professional human translator. They should not only be a native speaker of the target language, but also experienced in that business sector and have an in-depth knowledge of marketing and copywriting.This will ensure they get all the colloquialisms and cultural references correct, use the right terminology and accurately capture the styling and tone of your finely crafted marketing copy.

Businesses will also want to ensure that a native language search specialist optimises their landing pages for a good result. Then they can be confident that their various pages will perform well with the keywords that are the most used and most relevant in that language and for that region.So no, the machines aren't taking jobs just yet - but they're certainly winning the race in translation.

\section{The Advantages of Human Translation}

Even though translators can hardly be compared to, say, writers or journalists when it comes to making stories and articles from scratch, they are still considered experts in their field because of the way they hone a source text to fit a certain audience. In those terms, translators can be compared to editors who constantly shape, mold, and perfect a written piece for better public consumption.

To illustrate, here's the typical way a translator goes about his business: Once he has finishes a draft of his translation, he'll check whether or not his work contains any inconsistencies, misunderstandings, gaffes, and the like via constant and deliberate proofreading. From there, the translator will rewrite his proofread outline so that it will hide the translation marks. Being able to do so will help make the end product seem less like the result of a translation service and more like an original document.

\section{Comparing Machine and Human Text Translation}

In an attempt to spot light on the major practical differences between machine translation and human translation, the paper provides the following text to be translated by the two types of translation. The text is an extract written in English, taken from L.G. Alexander's book. The focus is to be on depicting, semantic and 
pragmatic differences manifested in the translated version. The translation is to be from English into Indonesian.

The source text:

\section{GOOD NEWS}

The secretary told me that Mr. Harmsworth would see me. I felt very nervous when I went into his office. He did not look up from his desk when I entered. After I had sat down, he said that business was very bad. He told me that the firm could not afford to pay such large salaries. Twenty people had already left. I knew that my turn had come.

'Mr. Harmsworth,' I said in a weak voice.

'Don't interrupt,' he said.

Then he smiled and told me I would receive an extra t 100 a year!

By: L.G. Alexander

\section{Machine Translation}

\section{KABAR BAIK}

Sekretaris mengatakan kepada saya bahwa Mr.Harmsworth akan melihat saya. Aku merasa sangat gugup ketika saya pergi ke kantornya. Dia tidak melihat ke atas dari mejanya ketika saya masuk. Setelah saya duduk, dia mengatakan bahwa bisnis itu sangat buruk. Dia mengatakan kepada sayabahwa perusahaan tidak mampu membayar gaji besar seperti. Dua puluh orang telah meninggalkan. Saya tahu bahwa giliran saya datang.

'Bapak.Harmsworth, "kataku dengan suara lemah. 'Jangan menyela,"katanya.

Lalu ia tersenyum dan mengatakan bahwa aku akan menerima tambahan 100 tahun! 
Oleh: L.G.Alexander

Human Translation

\section{BERITA BAIK}

Sekretaris berkata kepada saya bahwa Tuan Harmsworth meminta saya untuk menjumpainya. Saya merasa khawatir ketika saya masuk keruangannya. Dia tidak terlihat berada dimejanya ketika saya masuk. Setelah saya duduk, dia mengatakan bahwa bisnis belakangan ini sangat buruk. Dia mengatakan kepada saya bahwa perusahaan tidak mampu membayar gaji karyawan dalam jumlah besar. Dua puluh karyawan telah di PHK. Saya tahu bahwa ini adalah giliran saya untuk di pecat.

'Tuan Harmsworth,' saya ucapkan dengan nada yang pelan.

'Jangan memotong dulu,' katanya.

Kemudian dia tersenyum dan berkata kepada saya bahwa saya akan mendapatkan gaji tambahan sebesar seratus poundstraling tiap tahunnya.

\section{Oleh: L.G. ALEXANDER}

It is quite obvious, from the first reading of each translation, that machine translation is not that perfect rendering of the source text into the target text. The point is that the translated text, still, bears much of the traits characterizing the language of the source text; therefore, much should be said about how the use of language is violated as well as the meaning. Simultaneously, some focus is to be on to what extent the human translation has succeeded in transforming the source text into the target text depicting whether the translated text has the same effect as the source text.

\section{The use of language}

Violating the use of language is one of the main deficiencies that Machine Translation suffers from. For example we may see the following result of translation:

The source text: The secretary told me that Mr. Harmsworth would see me 
Human translation: Sekretaris berkata kepada saya bahwa Tuan Harmsworth meminta saya untuk menjumpainya.

Machine translation: Sekretaris mengatakan kepada saya bahwa Mr.Harmsworth akan melihat saya.

The source text: He did not look up from his desk when I entered.

Human Translation: Dia tidak terlihat berada dimejanya ketika saya masuk. Machine Translation: Dia tidak melihat ke atas dari mejanya ketika saya masuk.

The misuse of language, which is much manifested in machine translation, is mainly due to the literal nature of the translation. In the above example, the machine translation is a literal translation or instead a word-for-word translation; the reader can easily notice that there is no flexibility in the machine translation in that each word in the source text has been substituted orderly by another in the machine translation. Thus, it becomes clear that machine translation, is a translation, the focus of which is the source text rather than the target text. The word order is respected only in the source text; however, as far as the target text is concerned, no importance is given to the word order and the way words are linked resembles the way how words are linked in the source text.

Although the meaning can be comprehensible; nevertheless, the structure of languages are different and, hence, they should be respected for the sake of producing a well-formed translation in the target language. The inability of the machine translation to produce a well-structured text is due to its focus, as stated by Olivia Craciunescu, on the "comprehension" and not "the production of a perfect target text".

So far as the human translation is concerned, the above example can reveal, clearly how the human translator is capable of avoiding what have been criticized in the machine translation. The human version is a structure respecting and its focus has been in both the source text, in an act of comprehension, and the target text, in an act of producing a perfect translation. The human translator's flexibility allows them to move from language into another bearing in their minds the difference of structures between languages. 


\section{Violation of meaning}

No one can deny that the main rationale behind any translation is to transfer as much as possible the meaning intended by the source text's writer into the target text. Yet, in machine translation, this is not always the case in that sometimes the achieved meaning is ambiguous, distorted, and it becomes difficult to grasp it just like in the following example:

The source text: Twenty people had already left

Human Translation: Dua puluh karyawan telah di PHK.

Machine translation: Dua puluh orang telah meninggalkan.

The meaning 'left' in the machine translation is 'telah meninggalkan' while in human translation is 'PHK'. This association of meaning in machine translation is quite unfit for it is known that the act of telah meninggalkan in Indonesian language is not suitable to the meaning of the sentences because the meaning is ambigues. This is mainly, as stated before, due to the fact that machine translation focuses on the source text's language which is in this case English, as being different from Indonesian language.

\section{Conclusion}

Generally speaking, since it was first acknowledged as an academic discipline, translation studies have known the emergence of new methods of translation including so-called Machine Translation. However, its emergence was not at the expense of Human Translation for the latter proved to be the only subject capable of translating not only by means of substituting words for words, like Machine Translation, but also in terms of respecting linguistic, semantic, and more importantly cultural differences between languages.

This paper has been an attempt to draw a distinction between Machine Translation and Human Translation shedding light on the different characteristics of each one. The focus has been on depicting some the factors that render Human Translation more effective and flexible in comparison with Machine Translation. Thus, for the sake of illustrating, a practical text has been provided and it was translated by both Machine Translation and Human Translation. 
Therefore, the fact that machine translation is carried out by machines does not mean that humans are totally absent from the process of translation; nevertheless, there is human intervention, as in the case of Computer-Assisted Translation and in other cases of some translating machine programs that are limited in terms of the vocabulary provided by their programmed dictionaries. In this regard, the role of human translators is manifested in what is known as the process of pre-editing of the intended source text to be translated, and post-editing of the translated version provided by the machine translation.

\section{References}

Baker, M. (2015). Routledge Encyclopedia of Translation Studies. London and New York: Routledge Falmer.

Collin, C. (2006). Advanced Learners's English Dictionary. Harper Collin.

Graham, J. F. (1981). Theory of Translation (In Rose).

Newmark, P. (2000). A Textbook of Translation. New York: Prentice Hall.

Nida, E. A. (1969). Toward a Science of Translating. Leiden, Netherland: E.J. Brill.

Sukmadinata. (2009). Metode Penelitian Pendidikan (cet. V). Bandung: Remaja Posda Karya. 
This page intentionally left blank 